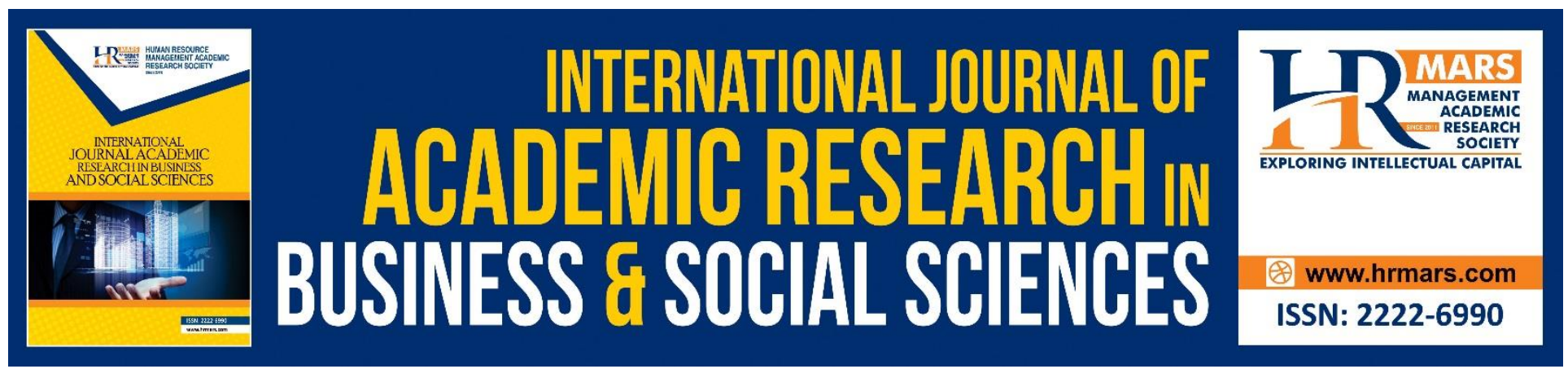

\title{
Analysis of Formation of the Decentralized Regional Public Organization: The Case of Tangerang City, Indonesia
}

\author{
Mustari Irawan and Irfan Ridwan Maksum
}

To Link this Article: http://dx.doi.org/10.6007/IJARBSS/v8-i9/4579

DOI: $\quad 10.6007 /$ IJARBSS/v8-i9/4579

Received: 13 July 2018, Revised: 22 August 2018, Accepted: 29 August 2018

Published Online: 12 September 2018

In-Text Citation: (Irawan \& Maksum, 2018)

To Cite this Article: Irawan, M., \& Maksum, I. R. (2018). Analysis of Formation of the Decentralized Regional Public Organization: The Case of Tangerang City, Indonesia. International Journal of Academic Research in Business and Social Sciences, 8(9), 118-137.

Copyright: (C) 2018 The Author(s)

Published by Human Resource Management Academic Research Society (www.hrmars.com)

This article is published under the Creative Commons Attribution (CC BY 4.0) license. Anyone may reproduce, distribute, translate and create derivative works of this article (for both commercial and non-commercial purposes), subject to full attribution to the original publication and authors. The full terms of this license may be seen

at: http://creativecommons.org/licences/by/4.0/legalcode

Vol. 8, No. 9, September 2018, Pg. 118 - 137

http://hrmars.com/index.php/pages/detail/IJARBSS

JOURNAL HOMEPAGE

Full Terms \& Conditions of access and use can be found at http://hrmars.com/index.php/pages/detail/publication-ethics 


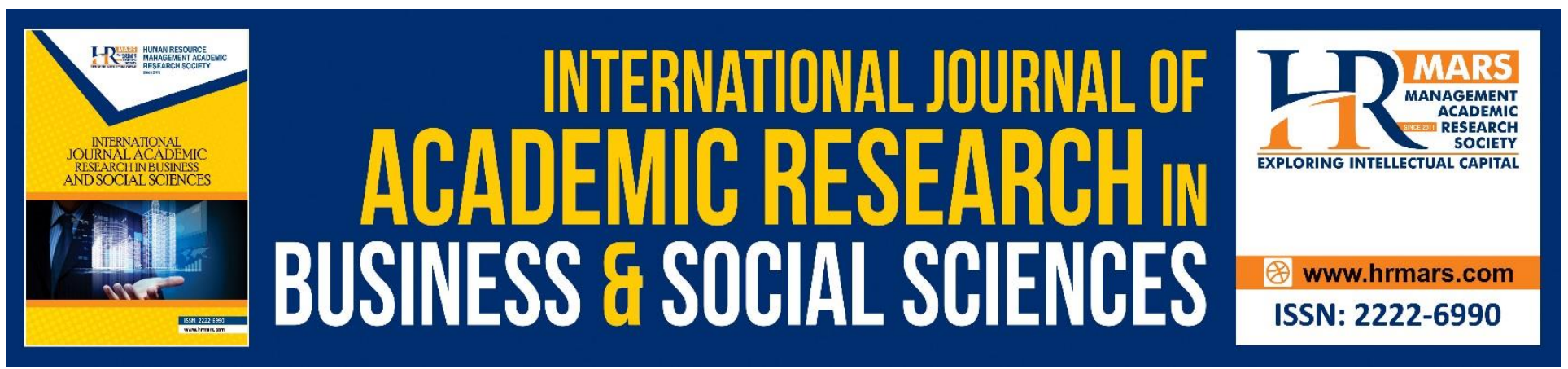

\title{
Analysis of Formation of the Decentralized Regional Public Organization: The Case of Tangerang City, Indonesia
}

\author{
Dr. Mustari Irawan ${ }^{1 *}$, and Dr. Irfan Ridwan Maksum² \\ ${ }^{1}$ Chairman of National Archives of the Republic of Indonesia \\ *Corresponding author: mustariirawan@yahoo.com \\ ${ }^{2}$ Professor, Faculty of Administrative Sciences, University of Indonesia
}

\begin{abstract}
This study analyses the formation of the decentralized regional public organization in the Tangerang City, Province of Banten, Indonesia. This study adopts the research paradigms of post-positivism as its philosophical basic framework. The qualitative approach based on the Soft Systems Methodology (SSM) is adopted to understand the real problems of the implementation of decentralization policies faced by public organization apparatus in carrying out their duties and functions, to explore the perceptions of the stakeholders to the problems, and to enhance the validity of the existing formal system model of decentralized regional public organization. To gather the data, the interview and Focus Group Discussion (FGD) were conducted with regional public officers, staff of the city secretariat, members of representative council, members of non-governmental organizations and communities. The study found that, at all levels, namely: macro, meso, and micro, the implementation of decentralization policies should be further improved. The regional regulation set up should focus on the needs and potential of the city, supported by the professional leaders that were not selected based on political interest, but based on the competent merit system. At the micro level, the regional apparatus at the regional offices of education, health services, and archives should be enhanced through changing in roles, functions, and institutional main tasks so that they would be adaptive, capable, and competent to support the implementation of decentralized policies. The internal environment related to the level of needs of the potential of the city should be provided with sufficient budget to support the offices' programs, while the external environment related to public services in organizing programs and activities of the regional offices should also be a focus of the decentralization policies to further improve the quality of public services provided to the people of Tangerang City, Indonesia.
\end{abstract}

Keywords: Decentralization, Regional Public Organization, Soft Systems Methodology, Public Service Performance. 
INTERNATIONAL JOURNAL OF ACADEMIC RESEARCH IN BUSINESS AND SOCIAL SCIENCES Vol. 8, No. 9, Sept. 2018, E-ISSN: 2222-6990 @ 2018 HRMARS

\section{Introduction}

The growth of democracy in developing countries is characterized by the establishment of a decentralization model in the government system. As a strategy towards democratizing the political system and accelerating sustainable development, decentralization is expected to strengthen the construction of public administration practices in developing countries (De Guzman and Reforma, 1993). The practice of decentralization in several Asian countries shows interesting model variations because it has a long development, beginning with a centralistic government system in 1980s (De Guzman and Reforma, 1993; and Ichimura and Bahl, 2009) and moving towards decentralized governance in 1990s (Cheema and Rondinelli, 2007). The United Nations have reconceptualized governance terminology as the exercise of political, economic and administrative authorities in management of a country's affairs. The shift of concepts from local government to local governance was also stated by Miller et al. (2000). The practices of decentralization in governance consist of administrative, political, fiscal, and economic aspects.

In Indonesia, the regulation on decentralization has been regulated by government policy in a new order government era (1966 - 1998) through the Law No. 5 of 1974, emphasized more on efficiency in service and development. The end of the new order government was followed by the enactment of Law No. 22 of 1999 in lieu of Law No. 5 of 1974. This law focuses on the model of local democracy. Since the Law No. 22 of 1999 has often created tension between the governments at the provincial level with the governments at the district level, the central government has enacted the Law No. 32 of 2004. This new law regulated the regional government, in which the authority of the central and regional governments is divided by regulating the distribution of government affairs underwent a fundamental change, as indicated by the enactment of the Law No. 38 of 2007, which stipulates 26 compulsory affairs that must be carried out by provincial governments and governments at the district level related to basic services.

In addition to compulsory affairs, there were 8 optional matters that have the potential to improve the welfare of the community in accordance with the conditions, characteristics, and superior potential of the region concerned in the context of developing regional autonomy. In Law No. 32 of 2004 concerning regional government, the terminology of government affairs is not authority. Government affairs are more defined as government or sector or smaller parts of the sector. Meanwhile, more authority is defined as the right to carry out one or more management functions, which include regulation, management, and supervision of a government affair.

The decentralization of government in Indonesia has long been the focus of the attention of state administration experts and researchers due to its arising problems. For more than four decades, like other newly independent countries, Indonesia has been struggling to formulate, adopt, and implement decentralized programs and reforms but had not shown an encouraging trend (Cohen et al., 1999). A crucial problem in decentralization is closely related to the distribution of authority and duties of central and local governments. Allocation of authority between the central and local governments, which is precisely determined and supervised by the central government (Cohen et al., 1999), lies in the level of provincial and district governments. Frederickson (1980) and Dunleavy and Hood (1994) emphasized the importance of the geographic aspects of state administration and the involvement of local communities as a key factor in maintaining decentralization. It is not only 
INTERNATIONAL JOURNAL OF ACADEMIC RESEARCH IN BUSINESS AND SOCIAL SCIENCES Vol. 8, No. 9, Sept. 2018, E-ISSN: 2222-6990 @ 2018 HRMARS

political decentralization is needed by the people in the region, but rather the efficiency and effectiveness of government administration (Treisman, 2007).

Although the values of decentralization have been stated in a variety of related policies, ranging from the Law to the regional regulations and Mayor Regulations, a number of trends especially concerning political and administrative behaviours are not easily explained by the concept of decentralization policy. According to Bromley (1989), the application of decentralization can be understood as a public policy that has three different levels based on the policy hierarchy. First, at the national regulatory stage, the policy level involves the Law on the Regional Governance and Government Regulations. This stage can be categorized as a macro level, because it is a regulation that becomes a legal umbrella in decentralization policy. Second, at the organizational level, is a regulatory stage in the regional government that can be categorized at the meso level. Finally, at the operational level is adopted as regional government regulations and Mayor Regulations that are related to regional organizations that can be understood as the micro level.

In general, the units of regional organizations in Indonesia have faced some problems in the practices of decentralization. These problems include: (1) the existence of a burden or excess function of the regional apparatus organization; (2) leaders of regional organizations have no competence in accordance with the position occupied; (3) the limited human resources both in terms of quantity and quality; (4) extraordinary externalities from several regional organizations; (5) apparatus of regional organizations have no standard operating procedure so that the implementation of work is based on habits or as it has been done before; and (6) the appointment of regional organization leaders was due to proximity to the Mayor, is more political interest than merit system.

Specifically, according to the Ministry of Home Affairs (2011), there were several problems at the macro level that are related to regional organizations. First, the tendency of regions to form regional organizations that are numerous and less based on the real needs of the region concerned. Second, the orientation of regional employees is to occupy very high and excessive structural positions. Third, the increase in functional positions is less developed in the regional bureaucracy. Fourth, there was a tendency of Ministries or Non-Ministerial Government Institutions to urge regions to make organizational structures as those in the centre with an offer to be given assistance.

At the meso level, the problem of the effectiveness of regional organizations at the city level is seen in functional relations between Regional Regulations and regional organizations, which are embodiments of decentralization of affairs. In addition, it is also related to the institutional function relation of the city's organization at the micro level. Thus, this article identify how the formation of regional organizations is practiced in three institutional levels (i.e., macro, meso, and micro), by taking the City of Tangerang, Banten Province, Indonesia as the case of study. The City of Tangerang is selected in this study as the city has recently involved in various programs of decentralization. Specifically, the study identifies the changes in regulation at the macro, meso, and micro levels that ensures the realization of the effectiveness of Regional Regulations, Regional Work Unit, and institutional performance of the regional organization of the City of Tangerang.

The findings of this study are expected to benefit the policy makers in enhancing the development of public administration of local government, focusing on the concept of urban decentralization and 
INTERNATIONAL JOURNAL OF ACADEMIC RESEARCH IN BUSINESS AND SOCIAL SCIENCES

Vol. 8, No. 9, Sept. 2018, E-ISSN: 2222-6990 @ 2018 HRMARS

conceptual contributions to local government in forming regional organizations at the city level. For the central government, it is hoped that the results of this study could be used as a structural reference in building the pattern of institutional relations between the government and the urban apparatus organization in accordance with the principles of applied decentralization. Meanwhile, for regional governments, the findings of this study are hoped could be used by decision makers as a tool to formulate and evaluate policies for the formation of existing regional organizations.

The rest of this study is structured in the following manner. Section 2 reviews relevant previous studies on decentralized governance, while Section 3 discusses the research method. Section 4 provides and discusses the findings of the study. Finally, Section 5 concludes the study.

\section{Selected Previous Studies}

\section{Public Administrative Theories}

The implementation of the policy of decentralization in developing countries grew with variety dynamics as a consequence of the application of modern government concepts, namely efforts to implement democratization of political system for sustainable development (De Guzman and Reforma, 1993). The practice of governance in developing countries is essentially the application of concepts of public administration as a discipline (Nigro and Nigro, 1989). According to Miftah (2008), the development of the science of public administration in Indonesia is divided into three major groups, namely: the classical public administration, new public management, and new public service. In 1960s, the public administration theories are enriched by the concept of organization and system of Katz and Kahn (1978), the thoughts on the administrative decentralization and political power of Kaufman (1969), and Waldo (1968) on the public administration in a time of revolution.

Meanwhile, the concept of new public management focused on leadership capabilities and market mechanisms in directing public programs by eliminating inefficient monopoly services by institutions and government bureaucrats. The concept of decentralization in the perspective of the new public management was triggered by Osborne and Gaebler (1994) as a principle of reinventing government, and later discussed by Osborne et al. (1998) on the case of reinventing government that are assumed as a transformation of spirit and performance of entrepreneurship into the government bureaucracy through the decentralization of the government system. Finally, the concept of the new public service is built from concepts of democratic citizenship, community and civil society models, humanism organizations, and postmodern science of public administration (Musolf and Seidman, 1980).

According to Florestal and Cooper (1997), the autonomy or decentralization is one of the challenges faced by public administration in addition to diversity, accountability, civil society, privatization, democratization, reengineering, and the empowering effect of high technology. The regional autonomy, especially with regard to the strengthening of local institutions, is a challenge, an opportunity, and a tendency towards a number of issues from public administration (Hughes, 2012). Within the framework of its implementation, the regional autonomy can be understood philosophically based on the principles of sharing of power, distribution of income, and empowering of regional administration. 
INTERNATIONAL JOURNAL OF ACADEMIC RESEARCH IN BUSINESS AND SOCIAL SCIENCES Vol. 8, No. 9, Sept. 2018, E-ISSN: 2222-6990 @ 2018 HRMARS

The change of concept from government to governance is a new paradigm in public administration. The United Nation defines governance as the exercise of political, economic, and administrative authority in the management of a country's affairs (Cheema and Rondinelli, 2007). Thus, economic governance encompasses decision-making processes that facilitate domestic economic activity and interaction between economic organizers, while political governance is a decision-making process to formulate a policy. In this concept of governance, decision-making is not only the authority of the government, but it involves citizens who demobilization through social organizations and the private sector or it is called as democratic governance (Cheema and Rondinelli, 2007).

The concept of good governance can be understood as a good governance process, involving stakeholders from various economic, socio-political activities, and the use of various resources (such as natural, financial, and human resources) by adhering to the principle of justice, equity, equality, efficiency, transparency, and accountability (Sedarmayanti, 2004). To the United Nations Development Program (UNDP), good governance has several characteristics, namely: participation, rule of law, transparency, responsiveness, consensus orientation, equity, effectiveness, efficiency, accountability, and strategic vision. In a latter study, Siong and Geraldine (2007) introduced the concept of dynamic governance. To them, the dynamism in governance is essential for sustained economic and social development and uncertain and fast changing environment, and this is increasingly demanding since the citizens are become more educated and more exposed to globalization. Thus, the dynamic governance implies a proactive approach to policy making and implementation that constantly anticipates future development, collects feedback, evaluates performance, and learns from other countries so that governance and institutional systems remain relevant and effective for economic and social development.

\section{Decentralization of Government}

Cheema and Rondinelli (2007) defined decentralization as the transfer of authority, responsibility, and resources- through deconcentration, delegation or devolution - from the centre to lower levels of administration, while Smith (1967) seen the decentralization as a unitary political system that includes devolution and deconcentration. Decentralization is the transfer of authority to bodies and groups within society in certain areas to take care of their own households. There were few types of decentralization, namely: political, functional, and cultural decentralization (Muslimin, 1960). Surianingrat (1981) further divided the decentralization into two: (i) position decentralization that is the dispersal of power from superiors to subordinates in relation to staffing with the intent to improve work smoothness, and (ii) state decentralization that is the surrender of power to regulate the region in its environment as an effort to realize the principle of democracy in the government of the country.

Apart from the deconcentration and devolution, the delegation is also a form of administrative decentralization (Cohen et al., 1999). By the end of 1980s, governments in many countries have offered three forms of decentralization, namely: deconcentration, devolution, and delegation. Deconcentration focuses on transferring administrative responsibilities from ministries or departments at the central level to administrative levels at the local and regional levels through the establishment of vertical offices in the regions and delegation of some authority in decision making to officials in vertical agencies. Devolution aims to strengthen local governance through assisting them with authority, responsibility and resources to provide services and infrastructure, protect 
INTERNATIONAL JOURNAL OF ACADEMIC RESEARCH IN BUSINESS AND SOCIAL SCIENCES Vol. 8, No. 9, Sept. 2018, E-ISSN: 2222-6990 @ 2018 HRMARS

public health and safety, and formulate and implement local policies. Finally, through delegations, the government at the central level transfers management authority to specific functions to semiautonomous organizations and state enterprises, regional planning and development agencies.

The implementation of decentralization, according to Hendratno (2009) is aimed at several goals and objectives include for political education, to exercise political leadership, to maintain political stability, to prevent the concentration of power in the Centre, to strengthen public accountability, and to increase elite sensitivity to community needs.

There have been many previous studies investigated the issue of decentralization implementation in Indonesia. Using Soft System Methodology (SSM), Supriyono (2007) studied the development of regional government institutions in urban infrastructure provision in Malang City of Indonesia. Muklir (2004) investigated the institutional restructuring in the context of regional government administration reform in the North Aceh District, while Situmorang (2002) explored the distribution model of government affairs between government, province and regency/city in Indonesia. Baedowi (2004) studies the implementation of regional autonomy policies in education in the District of Kendal and Surakarta, Indonesia and found that institutions and management of regional apparatus as a support system for policy implementation tend to be less effective in facilitating functions and facilitating implementation of education policies for the community, and apparatus in institutions.

In connection with the system thinking approach, Sukardiman (2004) investigated the design and development of public policy evaluation model with aggregation approaches and dynamic interaction of stakeholders for the case of deregulation policy in the Sea Transportation Sector 1983-2003 in Indonesia. Sujak (2004) explored the effectiveness of systems thinking approach in public policy formulation process in the department of revenue of Wonogiri City, Indonesia. Finally, Pudji (2007) studied the implementation of delegation of authority in the Special Capital Region of Jakarta.

All the above highlighted previous studies only investigated the implementation of regional autonomy or decentralized government, and none of them identified the changes in regulation at the macro, meso, and micro levels to ensure the realization of the effectiveness of decentralized regulations. Thus, this provide more motivation for this study to explore the changes in regulation at the macro, meso, and micro levels that ensures the realization of the effectiveness of regional regulations, regional working units, and institutional performance of the regional organization by taking the City of Tangerang, Indonesia as the case study.

\section{Research Method}

This study used the research paradigms of post-positivism as a philosophical basic framework. The design of this study is based on the qualitative of the Soft Systems Methodology (SSM). SSM is as a holistic approach that is considered as an interpretive approach (Hardjosoekarto, 2012). This method is suitable to be adopted in this study as it attempts to draw reality to the surface as an interpretation of character, models, signs or descriptions of certain conditions, situations or phenomena (Anwar, 2009). Basically, the nature of this study is a case study with the aim of conducting in-depth and thorough exploration. This study is more focused on the process of forming a decentralized regional public organization as a process of a particular system, focusing on education, health, and archival 
INTERNATIONAL JOURNAL OF ACADEMIC RESEARCH IN BUSINESS AND SOCIAL SCIENCES Vol. 8, No. 9, Sept. 2018, E-ISSN: 2222-6990 @ 2018 HRMARS

affairs in the Tangerang City, Indonesia. Judging from the shape of the unit under study from a qualitative perspective, the units of the study is shown in the following Table 1.

Table 1. Units of the Study

\begin{tabular}{|c|c|c|c|c|}
\hline $\begin{array}{l}\text { Descriptive } \\
\text { Approach }\end{array}$ & City & Executive and Legislative Body & $\begin{array}{c}\text { Non-Government } \\
\text { Organizations }\end{array}$ & Individual \\
\hline Case study & $\begin{array}{l}\text { Tangeran } \\
\text { g, Banten } \\
\text { Province }\end{array}$ & $\begin{array}{l}\text { Regional Head, Regional } \\
\text { Secretariat, } \\
\text { Service, Office, } \\
\text { Technical Institute, } \\
\text { House Representative Members }\end{array}$ & $\begin{array}{l}\text { Non-Government } \\
\text { Organizations }\end{array}$ & $\begin{array}{l}\text { Key informant } \\
\text { as a } \\
\text { stakeholder }\end{array}$ \\
\hline
\end{tabular}

Next, the SMS is used with the aims to: (i) understand the real world problem by the urban apparatus organization in carrying out its duties and functions, through exploring problems that tend not to be structured in a comprehensive, intense and profound way, which are then followed up by structured problems; (2) explore the perceptions of all stakeholders related to the problem to build a world review model on the problematic situation analyzed systemically; and (3) enhance the validity of the formal system model.

The selected regional public organization in Tangerang City, Banten Province, Indonesia with the representation of regional organizations in the affairs of education, health services, and archives are selected due to their similarity in level of heterogeneity. Meanwhile, the perpetrators are all stakeholders involved in the process of establishing a city-wide public organization that organizes three government affairs in the fields of education, health services and archives. The determination of participants or respondents in this study is based on the purposive sampling technique with the following criteria: (i) having involvement in the process of forming regional decentralized organizations, especially those that carry out government affairs in the fields of, education, health services, and archives at the city level; (ii) having the capacity of knowledge and insight in the field of public policy and regional governance organizations at the city level; and (iii) having the capacity of knowledge and insight and ability in regional government affairs.

To collect the primary data, the interview- with 9 Offices and their staff, 4 staff of the City Secretariat, 4 member of representative council, and 3 officers of NGOs and community members-, and Focus Group Discussion (FGD) was conducted, while for secondary data was obtained through review of references, documents, reports, notes and meeting minutes.

To analyze the qualitative data, a componential analysis is used, while to analyze the formation of regional decentralized public organizations in three levels: macro, meso and micro, the SSM is adopted. The data analysis is done by describing the symptoms obtained and analyzed comprehensively and systematically. The stages of data processing is as follows: First, the data material classification which includes four research substances, namely the pattern of the formation of regional organizations, institutional effectiveness, patterns of institutional development, and improvement of institutional effectiveness derived from interviews. The processing process includes transcribing the results of interviews, and grouping the results of the transcripts into each substance group and key informant. Second, the classification based on the units of symptoms studied in 
INTERNATIONAL JOURNAL OF ACADEMIC RESEARCH IN BUSINESS AND SOCIAL SCIENCES

Vol. 8, No. 9, Sept. 2018, E-ISSN: 2222-6990 @ 2018 HRMARS

accordance with the substance. Finally, the processing data based on the relationship between data components and unit of symptoms in the context of the focus of the problem.

\section{Findings and Discussion}

The process of forming unit of regional public organizations, as the focus of this study, is the mandate of Law No. 32 of 2004 concerning Regional Government. Meanwhile, in Law No. 22 of 1999, the term unit of regional public organizations was not used as the nomenclature. Law No. 22 of 1999 only mentioned regional apparatus. In Article 60 of the Act, it is stated that the apparatus of the regional public government consists of the regional secretariat, regional office, and other regional technical institutions.

\section{Regulations on Regional Public Government at the Macro Level}

Since the enactment of Law No. 22 of 1999, the dynamics in various regions have expanded and among them encouraged the expansion of regions. The number of districts has increased dramatically, including the City of Tangerang, since the Law No. 22 of 1999 was enacted. The problem of regional expansion, namely the steps to divide government units has not been proven to improve the situation. Therefore, it is very possible to reduce the turmoil of regional expansion, steps to empower the community, and efforts to provide space for community participation to be taken into account in the issuance of Law No. 32 of 2004 concerning regional government.

One formulation of implementing institutions in Law No. 32 of 2004 was given the nomenclature of the Working Unit of Regional Organization (WURO). Article 120 states that, "the apparatus of the regency/city consists of the regional secretariat, the regional representative council secretariat, the regional office, and the technical institutions of the regions, sub-districts and villages". In Tangerang City, the health services and education affairs are categorized as regional offices, while the archival office is categorized as a technical institution in the nomenclature. The archival office is a supporting element of the regional head's duties in the preparation and implementation of specific regional policies. In article 128 it is stated that, "the composition of the regional apparatus is stipulated in the regional regulation by taking into account the factors of task burden, area coverage and population based on government regulations".

In 2007, government regulation No. 38 of 2007 stipulated the distribution of government affairs between the central government, provincial governments, and district/city governments. In Article 2 of the government regulation No. 38 of 2007, it is affirmed about government affairs. It was stated that out of 31 government affairs, 26 of which were obligatory affairs transferred to the regions. This compulsory business is related to basic services. In addition, based on government regulation No. 41 of 2007 concerning regional organization equipment, the apparatus of the city area is an auxiliary element of the regional head in the administration of regional government, which consists of the regional secretariat, the representative council secretariat, regional offices, technical institutions, sub-districts, and villages.

The WURO is a regional working unit (RWU) outside the representative council secretariat, as an organizing element of regional government. An understanding of the allied perceptive of several business fields as contained in government regulation No. 38 of 2007 tends to be realized in the WURO nomenclature. Restrictions on the number of work units regulated in government regulation 
INTERNATIONAL JOURNAL OF ACADEMIC RESEARCH IN BUSINESS AND SOCIAL SCIENCES Vol. 8, No. 9, Sept. 2018, E-ISSN: 2222-6990 @ 2018 HRMARS

No.41 of 2007 Article 29 for service and Article 30 for regional technical institutions institutionally become psychological barriers of each WURO. For service unit consists of one secretariat and at most four fields, where the secretariat consists of three subsections and each field consists of at most three sections. The technical implementing unit in the WURO consists of one subdivision of administration and functional position group. Meanwhile the office as a technical institution consists of one administrative division and at most three sections. Further RWU formation is determined on the basis of regional regulations based on government regulation No. 41 of 2007 concerning WURO. Regional regulations for the Tangerang City govern the composition, position, main tasks of the RWU. Through the Mayor's regulation, the details of the RWU's duties, functions and work procedures are regulated. In legality, the process of establishing RWU has been carried out according to the laws and regulations, but the placement of the head of the RWU tends to be political.

\section{Regional Regulations on the Formation of WURO at the Meso and Micro Levels}

The formation and organizational structure of the education and the health services units are compiled based on the Tangerang City regional regulation No. 5 of 2008 concerning the establishment and composition of regional Organizations. Both of these offices are WURO which have the function of providing basic services to the community. Compared to the offices of education and the health service, the organizational structure of the office of regional archives is relatively smaller beside its echelon is also lower. The format of the regional archival office did not fully follow the format of the National Archives of the Republic of Indonesia, especially in the description of its functions.

Furthermore, the organization and work procedures of the education, health service, and archival working units are described in Tangerang Mayor Regulation No. 23 of 2008, No. 24 of 2008, and No. 45 of 2008. Regional regulation concerning the establishment and composition of the regional offices of education, health services, and archives are the regional regulations at the meso level, while the Mayor's regulations concerning the two working units and one technical institution, the regional archival office, are ruled are at the micro level, which determines the third organizational format of the WURO. In this study, the decentralization policy at three institutional levels was analyzed using the SSM approach. This approach does not confirm a presumption of 'right' and 'wrong' or 'good' and 'bad', it only traces the perceptions of respondents as a whole.

\section{Implementation of Decentralization Policies and Its Performance}

Based on the Tangerang City regional regulation No. 1 of 2008 concerning the government affairs, the city is divided into several functions implemented in the authority and duties of the WURO in assisting the smooth implementation of the duties of the regional head consisting of the Regional Secretariat, Regional Technical Institutions, Regional Offices, and Districts and Villages. Mayor Decree No. 1 of 2001 concerning Organization and Work Procedure of the Tangerang City Regional Secretariat stipulated that the Regional Secretariat is an element of local government staff led by the Regional Secretary who is under and is directly responsible to the Mayor. As an executive task unit, in accordance with provincial or municipal level governmental standards form agencies.

Regional Office is an implementing element of the Regional Government led by a Head of Service who is under and is responsible to the Mayor through the Regional Secretary. There are 13 Regional Offices in the City of Tangerang, namely: Health Office, Education and Culture Office, Agriculture 
Office, City Planning Office, Public Works Office, Housing and Settlement Office, Transportation Agency, Manpower Office, Land Service Office, Environment Service, Department of Industry, Trade, Cooperatives and Tourism, Department of Peace and Order, as well as the Population and Civil Registration Service. Regional Technical Institutions consist of four Agencies and six Offices headed by a Head of Agency and Office Head as supporting elements that assist the Mayor in the administration of Regional Governments for certain fields. The Head of the Office and Head of Office is under and is responsible to the Mayor through the Regional Secretary. Regional bodies consist of: Regional Planning Board, Regional Finance and Wealth Agency, Employment and Training Agency, and Regional Supervisory Agency, while Regional Offices consist of: Regional Archive Offices, Public Library Offices, Fire Extinguishing Offices, Investment and Licensing Offices, Offices Community Empowerment, and Electronic Data Processing Offices.

The implementation of decentralization policies in the Tangerang City resulted in a series of successes. This is shown by a significant increase in the provision of infrastructure and facilities in the affairs of the education, health services and archival sectors. Allocations of human resources that meet the requirements have also been carried out. Even in terms of financial allocations, the Tangerang City Government has produced savings of up to IDR1 trillion. This is marked by performance indicators where in the period of 2009 - 2013, the achievement of development targets based on the target indicators of good government management reached 91\%- 100\% (very high). However, the overall performance of each WURO has not yet achieved, as expected. As revealed by informants with an NGO background, it turns out that government public hospitals for example are not yet available in Tangerang City. In the field of education affairs, there have been many numbers of schools available, but the non-formal education institutions have been limited. Civil society activists demonstrated an irony that all government offices have used communication technology, such as providing wireless local area network (Wi-Fi) to access the internet, but this facility was not available at the places where local communities gather, such as in places of worship or other locations of social activities.

\section{Decentralization at the Macro Level}

At the macro level, the application of standards in the form of public policy, legislation concerning decentralization requires adjustments to the conditions of each region that are potential for diversity of resources, ethnicity, and local wisdom. The Tangerang City Government established WURO that directly provide services to the community and their implications are clearly and realistically felt structurally, namely the Education Office and the Health Services Office. In the formation of WURO and the appointment of officials, it is strongly influenced by political factors. WURO is formed as an embodiment of the promises and political programs that have been submitted by the elected Mayor during the campaign to the community, especially by its constituents.

Regulation on decentralization of regional government at the macro level can be compared between Law No. 32 of 1999, Law No. 32 of 2004, and the our recommendation is illustrated in Table 2. 
INTERNATIONAL JOURNAL OF ACADEMIC RESEARCH IN BUSINESS AND SOCIAL SCIENCES Vol. 8, No. 9, Sept. 2018, E-ISSN: 2222-6990 @ 2018 HRMARS

Table 2. Comparison between Law No. 32 (1999) and Law No. 32 (2004)

\begin{tabular}{|c|c|c|c|}
\hline Concept & Law No. 32 of 1999 & Law No. 32 of 2004 & Our Recommendation \\
\hline $\begin{array}{l}\text { Central } \\
\text { Government }\end{array}$ & $\begin{array}{l}\text { The Unitary State of } \\
\text { Republic of Indonesia } \\
\text { consisting of the } \\
\text { President and the } \\
\text { ministers according to } \\
\text { the principle of } \\
\text { decentralization }\end{array}$ & $\begin{array}{l}\text { President holds the } \\
\text { power of the } \\
\text { government of the } \\
\text { Republic of Indonesia } \\
\text { as in the } 1945 \\
\text { Constitution }\end{array}$ & $\begin{array}{l}\text { President is assisted by } \\
\text { ministers who are responsible } \\
\text { for government affairs. The } \\
\text { Minister has the authority to } \\
\text { provide guidance and } \\
\text { supervision to the regions. }\end{array}$ \\
\hline Decentralization & $\begin{array}{l}\text { Submission of } \\
\text { government authority } \\
\text { by the government to } \\
\text { autonomous regions } \\
\text { within the framework } \\
\text { of the Republic of } \\
\text { Indonesia }\end{array}$ & $\begin{array}{l}\text { The handover of } \\
\text { government authority } \\
\text { by the government to } \\
\text { autonomous regions } \\
\text { to regulate and } \\
\text { manage government } \\
\text { affairs in the Unitary } \\
\text { State of Republic of } \\
\text { Indonesia system }\end{array}$ & $\begin{array}{l}\text { The government is } \\
\text { responsible for the } \\
\text { establishment of a national } \\
\text { policy to maintain } \\
\text { harmonization, } \\
\text { synchronization between } \\
\text { regional governments and } \\
\text { regions. The government has } \\
\text { the authority to carry out } \\
\text { matters that create } \\
\text { externality across provinces } \\
\text { and countries }\end{array}$ \\
\hline Deconcentration & $\begin{array}{l}\text { Delegation of } \\
\text { authority from the } \\
\text { central government to } \\
\text { the governor as a } \\
\text { government } \\
\text { representative and/or } \\
\text { central equipment in } \\
\text { the area }\end{array}$ & $\begin{array}{l}\text { Delegation of } \\
\text { governmental } \\
\text { authority by the } \\
\text { government to the } \\
\text { Governor as } \\
\text { representative and/or } \\
\text { to certain regional } \\
\text { vertical agencies }\end{array}$ & $\begin{array}{l}\text { The regulation of government } \\
\text { affairs } \\
\text { general law that must be } \\
\text { done } \\
\text { the governor, regent, mayor } \\
\text { \& delegation from the mayor } \\
\text { to the district head }\end{array}$ \\
\hline $\begin{array}{l}\text { Task } \\
\text { Assistance }\end{array}$ & $\begin{array}{l}\text { Assignments from the } \\
\text { government to the } \\
\text { regions and villages, } \\
\text { from regions to } \\
\text { villages to carry out } \\
\text { certain tasks } \\
\text { accompanied by } \\
\text { financing, facilities, } \\
\text { infrastructure, and } \\
\text { human resources with } \\
\text { the obligation to } \\
\text { report their } \\
\text { implementation and } \\
\text { account for them. }\end{array}$ & $\begin{array}{l}\text { Assignment from the } \\
\text { government to the } \\
\text { regions and/or } \\
\text { villages of the } \\
\text { provincial } \\
\text { government to the } \\
\text { district/city and/or } \\
\text { village as well as from } \\
\text { the district/city } \\
\text { government to the } \\
\text { village to carry out } \\
\text { certain tasks. }\end{array}$ & $\begin{array}{l}\text { Implementation of co- } \\
\text { administration tasks is } \\
\text { unclear; therefore clear } \\
\text { criteria and consequences are } \\
\text { needed in the provision of co- } \\
\text { administration tasks. }\end{array}$ \\
\hline
\end{tabular}


INTERNATIONAL JOURNAL OF ACADEMIC RESEARCH IN BUSINESS AND SOCIAL SCIENCES Vol. 8, No. 9, Sept. 2018, E-ISSN: 2222-6990 @ 2018 HRMARS

\begin{tabular}{|c|c|c|c|}
\hline $\begin{array}{l}\text { Regional } \\
\text { Autonomy }\end{array}$ & $\begin{array}{l}\text { Authority of } \\
\text { autonomous regions } \\
\text { to regulate and } \\
\text { manage the interests } \\
\text { of local people } \\
\text { according to their own } \\
\text { initiative based on the } \\
\text { aspirations of the } \\
\text { community in line } \\
\text { with the law }\end{array}$ & $\begin{array}{l}\text { The right, authority, } \\
\text { and obligation of the } \\
\text { autonomous region to } \\
\text { regulate and manage } \\
\text { their own affairs and } \\
\text { local interests in line } \\
\text { with the laws and } \\
\text { regulations }\end{array}$ & $\begin{array}{l}\text { The province has the } \\
\text { authority to regulate and } \\
\text { manage the decentralization } \\
\text { that is its business, across } \\
\text { districts/cities and/matters } \\
\text { that have an impact over } \\
\text { district/city boundaries }\end{array}$ \\
\hline $\begin{array}{l}\text { Autonomous } \\
\text { Region }\end{array}$ & $\begin{array}{l}\text { The legal community } \\
\text { unit that has certain } \\
\text { territorial boundaries, } \\
\text { authority to regulate, } \\
\text { and manage the } \\
\text { interests of the local } \\
\text { community according } \\
\text { to its own initiative } \\
\text { based on the } \\
\text { aspirations of the } \\
\text { people in the Republic } \\
\text { of Indonesia. }\end{array}$ & $\begin{array}{l}\text { Legal community unit } \\
\text { that has territorial } \\
\text { boundaries and } \\
\text { authority to regulate } \\
\text { and manage } \\
\text { government affairs } \\
\text { and the interests of } \\
\text { local communities } \\
\text { according to their own } \\
\text { initiative based on the } \\
\text { aspirations of the } \\
\text { people in Indonesia }\end{array}$ & $\begin{array}{l}\text { The legal community unit that } \\
\text { has the territorial boundary } \\
\text { and authority to regulate and } \\
\text { manage government affairs } \\
\text { and the interests of the local } \\
\text { community according to its } \\
\text { own initiative based on the } \\
\text { aspirations of the community } \\
\text { and headed by the regional } \\
\text { head in Indonesia }\end{array}$ \\
\hline
\end{tabular}

Table 2. Continued

\begin{tabular}{|c|c|c|c|}
\hline Concept & Law No. 32 of 1999 & Law No. 32 of 2004 & Our Recommendation \\
\hline $\begin{array}{l}\text { Territory } \\
\text { Administration }\end{array}$ & $\begin{array}{l}\text { Governor's working } \\
\text { area } \\
\text { As a government } \\
\text { representative }\end{array}$ & - & $\begin{array}{l}\text { Governor's working area as } \\
\text { government representative }\end{array}$ \\
\hline $\begin{array}{l}\text { Urban } \\
\text { Communities }\end{array}$ & $\begin{array}{l}\text { Urban village work } \\
\text { area as district and/or } \\
\text { regional government } \\
\text { of } \\
\text { city under the sub- } \\
\text { district }\end{array}$ & - & $\begin{array}{l}\text { The village working area as a } \\
\text { regional apparatus at the city } \\
\text { level under the sub-district }\end{array}$ \\
\hline $\begin{array}{l}\text { Government } \\
\text { Area }\end{array}$ & $\begin{array}{l}\text { Head of region along } \\
\text { with other } \\
\text { autonomous regions } \\
\text { as an executive body } \\
\text { in the administrative } \\
\text { area. }\end{array}$ & $\begin{array}{l}\text { Governors, Regents or } \\
\text { Mayors and regional } \\
\text { apparatuses as } \\
\text { regional government } \\
\text { administrators. }\end{array}$ & $\begin{array}{l}\text { It is necessary to regulate the } \\
\text { existence of regional } \\
\text { leadership consultation as a } \\
\text { coordination forum between } \\
\text { regional leaders and vertical } \\
\text { agency leaders, in addition to } \\
\text { the clarity of the role of the } \\
\text { Governor, Regent or Mayor, }\end{array}$ \\
\hline
\end{tabular}


INTERNATIONAL JOURNAL OF ACADEMIC RESEARCH IN BUSINESS AND SOCIAL SCIENCES Vol. 8, No. 9, Sept. 2018, E-ISSN: 2222-6990 @ 2018 HRMARS

\begin{tabular}{|c|c|c|c|}
\hline & & & $\begin{array}{l}\text { and regional apparatus as the } \\
\text { organizer of the Local } \\
\text { Government }\end{array}$ \\
\hline $\begin{array}{l}\text { Government } \\
\text { Area }\end{array}$ & $\begin{array}{l}\text { Implementation of } \\
\text { Local Government } \\
\text { Autonomy by the local } \\
\text { government and the } \\
\text { representative } \\
\text { consultative member } \\
\text { and/or urban areas } \\
\text { under the sub-district }\end{array}$ & $\begin{array}{l}\text { The administration of } \\
\text { government affairs by } \\
\text { the regional } \\
\text { government and the } \\
\text { representative } \\
\text { consultative member } \\
\text { based on the principle } \\
\text { of autonomy as } \\
\text { broadly as possible in } \\
\text { the Indonesian } \\
\text { system }\end{array}$ & $\begin{array}{l}\text { Need to be clearly regulated. } \\
\text { The stand and hub between } \\
\text { the representative } \\
\text { consultative member and the } \\
\text { regional head as the regional } \\
\text { organizer element so as to } \\
\text { ensure the checks and } \\
\text { balances in their relations to } \\
\text { realize the welfare of the } \\
\text { people. }\end{array}$ \\
\hline Village & $\begin{array}{l}\text { Unitary legal } \\
\text { community area that } \\
\text { have the authority to } \\
\text { regulate according to } \\
\text { the principle of } \\
\text { decentralization }\end{array}$ & $\begin{array}{l}\text { A legal community } \\
\text { unit that has } \\
\text { authorized territories } \\
\text { to regulate and } \\
\text { manage the interests } \\
\text { of the local } \\
\text { community based on } \\
\text { the origin and local } \\
\text { customs that are } \\
\text { recognized and } \\
\text { respected in the } \\
\text { Republic of Indonesia } \\
\text { system }\end{array}$ & $\begin{array}{l}\text { It has been regulated in a } \\
\text { special Law included } \\
\text { Villages. Villages self- } \\
\text { in community-based } \\
\text { community } \\
\text { government or government } \\
\text { carry out things related to } \\
\text { customs and traditions and } \\
\text { not local self-government as } \\
\text { well as provinces, } \\
\text { districts/cities. }\end{array}$ \\
\hline
\end{tabular}

From the comparison as illustrated in Table 2, the restructuring step in the regulation of government affairs should be carried out on Law No. 32 of 2004. Restructuring the architecture of the division of government affairs between levels of government could be done in the following steps. First, the concept used to divide government affairs into exclusive or absolute affairs and concurrent affairs. Second, it should be considered to clarify the way in which central affairs are carried out by determining the affairs that should be carried out by the Central Government directly by using deconcentration and co-administration.

\section{Decentralization at the Meso Level}

At the meso level, the focus is the institutional organization of the regional apparatus including the WURO leaders and their staff. In addition to coordinating the determination of the dimensions of decentralization, the pouring is also coordinating the implementation of government regulations. Decentralization implemented through Law No. 32 of 2004 must actually be in line with Law No. 43 of 1999 (later on become the Law No.5 of 2014 concerning State Civil Apparatus) relating to the issue of placement of officials who must be in accordance with the merit system based competency. The placement of officials who have the required competencies and the open recruitment has been 
INTERNATIONAL JOURNAL OF ACADEMIC RESEARCH IN BUSINESS AND SOCIAL SCIENCES Vol. 8, No. 9, Sept. 2018, E-ISSN: 2222-6990 @ 2018 HRMARS

introduced in 2012. The establishment of regional apparatus organizations is based on government regulation No. 38 of 2007 concerning the Division of Government Affairs.

Previously, the City of Tangerang Government was not based on PP No.8 in 2003 because it considered that the RWU was in line with needs. Several years after that, the City Government conducted a study to change the existing RWU, and almost at the same time the Government issued its regulations No. 38 and No. 41 of 2007 as a derivative of Law No. 32 of 2004. Government Regulation No. 41 of 2007 is the legal basis for the Tangerang City government in the establishment of RWU. Although the government regulation provides space for the Tangerang City government to form a maximum pattern of RWU, because it meets one criterion - the Regional Budget was above the IDR1 trillion - but the City Government chosen an intermediate pattern by looking at the needs of the community.

In the formation of a WURO through a study involving other related WURO. This is done to avoid overlapping offices, as well as to strengthen each other in coordination. Organizational WURO needs were elaborated in structural and functional positions based on job analysis, workload analysis, which could then be summarized into an organizational structure of each organization. As for internal and external factors that were determinants and might be considered in the process of forming regional apparatus organizations based on the existence of academic studies in the form of academic texts, legal products, the preparation of structures, functions, and main tasks of the organization. Every regional apparatus organization, in this case commonly referred to as regional task force of WURO was highly influenced by its leadership. The Head of WURO has a very strategic role in running the wheels of government organizations. Therefore, the chosen person must be truly capable of carrying out his duties well. Every organization requires clear and predictable budget planning. The same is true for each WURO.

However, in the preparation of the budget, especially related to the amount of the budget, it must be clear, including the determination of the amount of budget of each WURO and based on the needs of the performance plan that has been submitted previously. In addition to the Head of the WURO, the important thing was to determine the quality of the performance of the regional apparatus. There were many factors that influence the performance of WURO, including the compatibility between work plans and carried-out activities, institutional supervision and evaluation, and implementing institutional guidance. While the factors to overcome these obstacles, among others, were the optimization of the main tasks and functions of each WURO, the further integration of various WUROs, the holding of socialization and information on work throughout the community, and the equal workload balance and coordination between various WUROs so that there was no overlap of activity.

\section{Decentralization at the Micro Level}

At the Micro level, the interviews is conducted with the focus is on the optimization and direction of increasing the effectiveness of adaptive regional organizations, the placement of officials, and the needed competencies of the officials. There were many factors behind the formation of regional organizations, both internal and external. As for internal factors that were determinants and must be considered in the process of forming regional apparatus organizations, among others, related to the determination of the function of the work unit that is aligned with the number of fields formed. In 
INTERNATIONAL JOURNAL OF ACADEMIC RESEARCH IN BUSINESS AND SOCIAL SCIENCES Vol. 8, No. 9, Sept. 2018, E-ISSN: 2222-6990 @ 2018 HRMARS

addition human resource capacity was also a factor that influences the work unit. The volume of work and advances in sciences and technology were also factors influencing the formation of RWU.

In addition to internal factors, there were also external factors that influence, including the preparation of the structure, function and main tasks of the WURO organization. In the view of NGOs, the process of forming regional apparatus organizations, from the beginning to the stipulation in the regional regulation, especially for the Tangerang City's education, health services, and archival offices was related to reforming the bureaucracy at the WURO level, which was directly emphasized by the department of organization and governance. In relation to the process of structuring the organization, functions, and main tasks of each WURO of education, health services, and archival offices, what needs to be emphasized was to form organizational plan first, human relations, and based on competence. Some NGOs were also concerned about highlighting a number of things that have the potential to disrupt the performance of regional organizations. One of them was by observing internal factors that were determinants, namely the need for loyalty, lack of synchronization between the needs of the organization and the regulations that have been issued, and the formation of organizations was less touching to the community. While the external factors, namely the needs of the community were more idealistic and the system applied was less supportive. Meanwhile, specifically related to the education office, it turned out that the NGOs were also paying great attention. According to several NGO figures, the factors that must be considered in the formulation of the structure, function, and main tasks of the organization of the education office were to increase cheaper, quality and affordable education and free education. Likewise with the health office, the factors that must be considered in the formulation of the structure, function, and main tasks of the health service office were optimizing the maximum service for the community and promoting the Poor Family Health Insurance Program. Whereas for the Archival Office that need to be emphasized was to use a lot of hardware, websites, and make them integration with national archives.

\section{Implications of the Findings}

Based on the above findings and discussion, some implications could be derived for further improve the implementation of decentralization policies to enhance the performance of regional public organization in Tangerang City, Indonesia. At the macro level, Law No. 32 of 2004 concerning Regional Government and Government Regulation No. 41 of 2007 concerning the Organization of Regional should be revised to expand and accommodate several heterogeneity aspects of each city. Some points of view should be considered in the revision of laws and regulations, as follows:

1. The regulations regarding norms, criteria and standards in the development of regional organizations are needed. Arrangements that encourage regions to be able to form organizations in accordance with the authority they possess, characteristics of regional potential and needs, regional financial capacity, availability of apparatus resources and development of partnerships between regions and with third parties.

2. The organizational structure of the regional apparatus should be tightening in order to have an organizational structure in accordance with the priority of basic service needs as well as potential sectors that are potentially developed in the region.

3. There is a need for regulation to regulate the region to carry out job analysis as a basis for reforming its apparatus and government apparatus. This job analysis provides information 
INTERNATIONAL JOURNAL OF ACADEMIC RESEARCH IN BUSINESS AND SOCIAL SCIENCES Vol. 8, No. 9, Sept. 2018, E-ISSN: 2222-6990 @ 2018 HRMARS

about job requirements, job classification, job competency standards, remuneration system and employee information system.

4. The regulations should also regulate the functional positions of the apparatus. If the region is able to develop positions functionally significantly, then the region can reduce pressure to create a fat structure in addition to providing opportunities for the development of employee professionalism in improving public services.

5. There is a need to regulate performance-based incentives so that it can change the paradigm of regional employees who tend to change structural positions. Performance-based incentives must be supported by clear and standard performance measures.

6. The limits amount of budget for personnel expenditure should also be regulated. The budget for personnel expenditure does not exceed the budget amount provided for public services.

Meanwhile, at the meso level with changes in national regulations with regard to regional governments, especially in the formation of regional organs, the local government should adjust the regional regulations on the WURO so that regional organizations can be formed in accordance with the principles of decentralization. Therefore, the arrangements should be made to encourage the regional government to analyze the position and make it as a basis for reforming its governance tools. Job analysis should be able to provide information about job requirements, job classifications, job competency standards, remuneration, and personnel information systems.

Finally, at the micro level with the improvement of regional regulations, the development of the WURO's main tasks, organizational functions, and roles in order to be adaptive to the dynamics of change is carried out through efforts to improve leadership competencies and capacity through open selection that is free from political interest, work management improvement, and human resource quality improvement apparatus based on the merit system. In addition, the development of functional positions should provide a directive recommendation to the possibility of reducing the existing pressure, which makes the structure bigger because it accommodates a large number of workers or employees. In addition, the development of functional positions would be able to increase the professionalism of city government employees, which has implications for improving the quality of regional services to the public.

In addition, at the micro-level, the improvement of the effectiveness of the organizational performance was carried out through the formulation of a vision and mission in line with the main tasks and functions based on the concept of local governance, where the WURO should be more open, transparent, accountable, and professional. The preparation of a clear vision and mission from the WURO, should simultaneously compile a standard assessment and evaluation of performance or key work indicators that periodically assess the accuracy of the bureaucratic structure with the regional vision and mission. The implication is that regions would be able to develop bureaucratic structures that are in line with regional needs and anticipate long-term interests. Correspondingly, local governments should also be recommended to formulate regulations that limit the amount of employee budget in accordance with the needs and interests, characteristics, and potential of the city so that the proportion of the budget for public services could increase.

\section{Conclusion}

Analysis of the formation of regional organizations in the City of Tangerang, Indonesia should not be understood and limited only to changes in the format of structures and organizations. However, it 
INTERNATIONAL JOURNAL OF ACADEMIC RESEARCH IN BUSINESS AND SOCIAL SCIENCES

Vol. 8, No. 9, Sept. 2018, E-ISSN: 2222-6990 @ 2018 HRMARS

should be viewed from the broad and comprehensive understanding of the laws and regulations under the umbrella of the Law on Regional Government, Government Regulations, Regional Regulations, and Mayor Regulations. By adopting the Soft Systems Methodology (SSM) with several modifications and restrictions to approach and trace problematic situations related to processes and establishment of working units of regional public organizations in Tangerang City, Indonesia. Therefore, this study tried to look at three institutional levels, namely: macro, meso and micro. With regards to the implementation of decentralization policies in the Tangerang City, some conclusions could be drawn.

At the macro level, the analysis of changes of national regulation was focused on the changes in Law No. 32 of 2004 concerning Regional Government comprehensively, especially in relation to the regulation of regional organization that provides space for changes in government regulations regarding the regional organization become the basis for the implementation of the Tangerang City regional regulation in forming regional organizations.

At the meso level, analysis of changes was focused on the improvement of regional regulations, which were based on the regulatory provisions concerning regional government, especially those relating to the establishment of regional organizations. Regional regulation development focuses on institutional aspects that are in accordance with the needs and potential of the city, leaders of professional and competent WURO were not based on political interest, but the human resources that are based on competent merit system and focus on functional positions, programs that are in line with the WURO's vision and mission of regional budget.

Finally, at the micro level, analysis of changes in structure, main tasks and functions in the Regional Apparatus Organization in the three WUROs, the regional offices of education, health services, and archives should be enhanced through changing in roles, functions, and institutional main tasks of the regional organizations so that the WURO would be able to be adaptive, leaders who have the capability and capacity of competency and systematic work management with the support of changes in human relation personnel. The internal environment that is related to the level of needs, the potential of the city, and an increase in the budget for the offices of regional education, health services, and archives should be sufficiently available to support the offices' programs, while the external environment that is related to public services in organizing programs and activities of the WURO should also be a focus of the decentralization policies to further improve the quality of services provided by the regional organizations to the people of Tangerang City, Indonesia.

\section{References}

Anwar, R. (2009). Pengembangan model tentang pengaruh able people dan agile process terhadap dynamic capabilities dalam proses kebijakan public: Studi kasus pelayanan bidang pendidikan di Kabupaten Jembrana, Propinsi Bali. Dissertation. Jakarta: Faculty of Social and Political Sciences, University of Indonesia.

Baedowi. (2004). Implementasi kebijakan otonomi daerah bidang pendidikan: Studi kasus di Kabupaten Kendal dan Kota Surakarta. Dissertation. Jakarta: Faculty of Social and Political Sciences, University of Indonesia.

Bromley, D. W. (1989). Economic interests and institutions: the conceptual foundations of public policy. Daniel W. Bromley. New York and Oxford: Basil Blackwell. 
INTERNATIONAL JOURNAL OF ACADEMIC RESEARCH IN BUSINESS AND SOCIAL SCIENCES

Vol. 8, No. 9, Sept. 2018, E-ISSN: 2222-6990 @ 2018 HRMARS

Cheema, G. S., \& Rondinelli, D. A. (Eds.). (2007). Decentralizing Governance: Emerging Concepts and Practices. Brookings Institution Press.

Cohen, J. M., Peterson, S. B., \& Peterson, S. B. (1999). Administrative Decentralization: Strategies for Developing Countries (pp. 94-96). West Hartford, CT: Kumarian Press.

De Guzman, R. P., \& Reforma, M. A. (1993). Decentralization towards Democratization and Development. European Secretariat.

Dunleavy, P., \& Hood, C. (1994). From old public administration to new public management. Public Money \& Management, 14(3), 9-16.

Florestal, K., \& Cooper, R. (1997). Decentralization of Education: Legal Issues. The World Bank.

Frederickson, H. G. (1980). New Public Administration. University, Ala: University of Alabama Press.

Hardjosoekarto, S. (2012). Construction of social development index as a theoretical research practice in action research by using soft systems methodology. Systemic Practice and Action Research, 25(6), 493-509.

Hendratno, E. T. (2009). Negara Kesatuan, Desentralisasi, dan Federalisme. Jakarta: Graha Ilmu.

Hughes, O. E. (2012). Public Management and Administration: An Introduction. Macmillan International Higher Education.

Ichimura, S., \& Bahl, R. W. (2009). Decentralization Policies in Asian Development. World Scientific.

Katz, D., \& Kahn, R. L. (1978). Organizations and the System Concept: Classics of Organization Theory, 161-172.

Kaufman, H. (1969). Administrative decentralization and political power. Public Administration Review, 29(1), 3-15.

Miftah, T. (2008). Ilmu Administrasi Publik Kontemporer. Jakarta: Kencana.

Miller, W., Dickson, M., \& Stoker, G. (2000). Models of Local Governance: Public Opinion and Political Theory in Britain. Springer.

Ministry of Home Affairs. (2011). Academic Text of Proposed Amendment to Law No. 32/2004. Jakarta: Kementerian Dalam Negeri.

Muklir, I. (2004). Restrukturisasi institusi dalam rangka reformasi administrasi pemerintahan daerah: Studi pada Kabupaten Aceh Utara. Dissertation. Jakarta: Faculty of Social and Political Sciences, University of Indonesia.

Ribawanto.(2005). Restrukturisasi organisasi dalam rangka reformasi administrasi pemerintah daerah. Jurnal Ilmu Administrasi Publik, 5(1), 26-38.

Muslimin, A. (1960). Ichtisar Perkembangan Otonomi Daerah, 1903-1958. Jakarta: Djambatan.

Musolf, L. D., \& Seidman, H. (1980). The blurred boundaries of public administration. Public Administration Review, 124-130.

Nigro, F. A., \& Nigro, L. G. (1984). Modern Public Administration, 5th ed. New York: Harper and Row.

Osborne, D., \& Gaebler, T. (1994). La reinvención del gobierno. La influencia del espíritu empresarial en el sector público. Editorial Paidós, Barcelona, España, 494.

Osborne, D., Plastrik, P., \& Oteiza, D. A. (1998). La reducción de la burocracia: cinco estrategias para reinventar el gobierno (Vol. 446). Buenos Aires: Paidós.

Pudji, D. U. (2007). Pelaksanaan pelimpahan kewenangan di Provinsi Daerah Khusus Ibukota. Dissertation. Jakarta: Faculty of Social and Political Sciences, University of Indonesia.

Sedarmayanti. (2007). Good Governance (Kepemerintahan yang Baik) dan Good Corporate Governance (Tata Kelola Perusahaan yang Baik). Bandung: Mandar Maju.

Siong, N. B., \& Geraldine, C. (2007). Dynamic Governance: Embedding Culture, Capabilities and Change in Singapore. World Scientific. 
INTERNATIONAL JOURNAL OF ACADEMIC RESEARCH IN BUSINESS AND SOCIAL SCIENCES

Vol. 8, No. 9, Sept. 2018, E-ISSN: 2222-6990 @ 2018 HRMARS

Situmorang, S. (2002). Model pembagian urusan pemerintahan antara pemerintah, provinsi, dan Kabupaten/Kota. Dissertation. Jakarta: Faculty of Social and Political Sciences, University of Indonesia.

Smith, B. C. (Ed.). (1967). Field Administration: An Aspect of Decentralisation. Routledge \& K. Paul.

Sujak, A. (2004). Efektivitas pendekatan berpikir sistem dalam proses perumusan kebijakan publik: Riset aksi di Dinas Pendapatan Daerah Kabupaten Wonogiri. Dissertation. Jakarta: Faculty of Social and Political Sciences, University of Indonesia.

Sukardiman. (2004). Rancang bangun model evaluasi kebijakan publik dengan pendekatan agregasi kepentingan dan interaksi dinamis stakeholders: Studi kasus kebijakan deregulasi pada sektor angkatan laut 1983-2003. Dissertation. Jakarta: Faculty of Social and Political Sciences, University of Indonesia.

Supriyono, B. (2007). Pembangunan institusi pemerintah daerah dalam penyediaan prasarana perkotaan di Kota Malang. Dissertation. Jakarta: Faculty of Social and Political Sciences, University of Indonesia.

Surianingrat, B. (1981). Desentralisasi dan Dekonsentrasi Pemerintahan di Indonesia: Suatu Analisa. Dewaruci Press.

Treisman, D. (2007). The Architecture of Government: Rethinking Political Decentralization. Cambridge University Press.

Waldo, D. (1968). Public administration in a time of revolutions. Public Administration Review, 28(4), 362-368. 